\title{
Effect of formaldehyde on some post-harvest qualities and shelf-life of selected fruits and vegetables
}

\author{
Raiya Adiba Antora, Md. Pavel Hossain, Syeeda Shiraj-Um-Monira and Mohammad Gulzarul Aziz
}

Department of Food Technology and Rural Industries, Faculty of Agricultural Engineering and Technology, Bangldesh Agricultural University, Mymensingh- 2202, Bangladesh

\begin{tabular}{|c|c|}
\hline ARTICLE INFO & Abstract \\
\hline $\begin{array}{l}\text { Article history: } \\
\text { Received: } 29 \text { November } 2017 \\
\text { Accepted: } 18 \text { January } 2018\end{array}$ & $\begin{array}{l}\text { In Bangladesh, a lot of fruits and vegetables have been accused of having prolonged shelf-life by } \\
\text { formaldehyde adulteration. So, an evaluation of the effect of formaldehyde was carried out by treating } \\
\text { mango, litchi and oyster mushroom with different concentrations of formaldehyde and assessing their } \\
\text { quality parameters. The three samples were dipped in } 0 \%, 1 \%, 5 \% \text { and } 10 \% \text { formaldehyde solutions for } 15\end{array}$ \\
\hline $\begin{array}{l}\text { Keywords: } \\
\text { Formaldehyde, adulteration, } \\
\text { shelf-life, preservative }\end{array}$ & $\begin{array}{l}\text { weight loss were observed during storage at every alternate day. No significant increase in post-harvest } \\
\text { quality and shelf-life was observed for mango and litchi treated with formaldehyde compared to control. }\end{array}$ \\
\hline $\begin{array}{l}\text { Correspondence: } \\
\text { Mohammad Gulzarul Aziz } \\
\text { (aziz_ftri@bau.edu.bd.) }\end{array}$ & $\begin{array}{l}\text { they lost their commercial freshness. The formaldehyde solutions did not have any significant effect on } \\
\text { weight loss. So, formaldehyde is not a useful preservative to improve the post-harvest quality and shelf- } \\
\text { life of fresh fruits and vegetables. }\end{array}$ \\
\hline
\end{tabular}

\section{Introduction}

Contamination and adulteration in foods have become an extreme situation in Bangladesh in the recent years. Numerous physical illness as well as deaths has been reported due to the consumption of adulterated foods (Ali, 2013a; Ali, 2013b). Various toxic chemicals and colorants are reported to use in foods to increase their stability, such as DDT (Dichloro Diphenyl Trichloroethane) in dried fish, textile colorants as a food coloring agent, urea fertilizer in puffed rice, which can cause cancer, reproductive problems, indigestions, allergies and other severe physical illness (Bhuiyan et al., 2008; Rahman \& Alam, 1997; Khan, 2012a; Munim, 2011, Radomski, 1974; Khan 2012b). Weak regulatory controls, insufficient transportation facilities, increasing consumer demand, but inadequate storage and refrigeration conditions are resulting tendency of fraudulent of producers to increase the shelf life (UN, 2012). In Bangladesh and South-East Asian countries, there are reports that formalin, which is the $37-50 \%$ of an aqueous solution of formaldehyde (Kawamata \& Kodera, 2004), is added to foods to increase its storage stability (Uddin et al., 2011). According to world health organization (WHO, 2006) and the Agency for Toxic Substances and Disease Registry (ATSDR, 1999), it is flammable, highly reactive and readily polymerized in gaseous form but stable over time in liquid form. Formaldehyde is mainly used in the production of wood products, papers, textile fibers, plastics, cosmetics, adhesives, nail hardeners, disinfectants, foaming insulators, etc. (WHO, 2006). It is recently classified as carcinogenic to humans (IARC, 2004).
The main route of exposure of this hazardous chemical is through the air (by occupational exposures, such as formaldehyde and resin production), dermal contact smoking (receiving about0.38 mg/day) and water (Mamun, 2014; Takahashi et al., 2007). According to some reports, formaldehyde can also be administrated in foods and drinking water naturally and artificially when used as a preservative (Restani et al., 1992; Tomkins et al., 1989). Formaldehyde accumulates in frozen food during storage and reacts with protein that causes protein denaturation and muscle toughness (Sotelo et al.,1995). Seafoods, crustaceans and fish proteins undergo biochemical and rheological changes due to high storage temperatures and prolonged storage time; these are reported to be due to the effect offormaldehyde produced from trim ethylamine oxide (TMAO) (Badii \& Howel, 2003; Bianchi et al., 2007). In Bangladesh, producers as well as wholesalers are accused of adding formalin illegally to perishable fruits and vegetables, fishes and some other food products prolong their shelflife. Tons of fruits have been destroyed in recent years based on the media reports to protect the consumers from taking the formalin-adulterated food, though there was no scientific evidence of the presence of formalin beyond the permitted level in those. Formaldehyde can naturally occur in various amounts:3-60 mg/kg in several fruits and vegetables, $1 \mathrm{mg} / \mathrm{kg}$ in dairy product, $6-20 \mathrm{mg} / \mathrm{kg}$ in meat and fish and $1-100 \mathrm{mg} / \mathrm{kg}$ in shellfish(WHO, 2000). In Europe, the presence of formaldehyde is permitted to a maximum level of $25 \mathrm{mg} / \mathrm{kg}$ as a breakdown product of hexamethylene tetramine in the production of cheese, and an amount up 
to $50 \mathrm{mg} / \mathrm{kg}$ in gelling additives as a preservative (Wahed et al., 2016). The European Food Safety Authority (EFSA, 2014) has limited daily exposure to formaldehyde from food of both animal and plant origin to $100 \mathrm{mg} / \mathrm{kg}$ food per day. Dietary exposure is to be limited to about $11 \mathrm{mg} / \mathrm{kg}$ food per person per day on average (AFSSA, 2004). Though there are some reports of addition of formaldehyde in cheese, fish, milk and gelling additives, but other than the media reports, no scientific evidence is found till now that can scientifically prove the formalin addition to fruits and vegetables. As formaldehyde generally works on protein, it may not be effective on fruits and vegetables because they have a naturally lower amount of protein (Kiernan, 2000).

Based on aforementioned concerns of food adulteration in Bangladesh, this study was conducted to evaluate the effect of formaldehyde on post-harvest quality and shelf life of mango, litchi and mushroom (positive control). It is expected that the findings of the study will provide actual information to the consumers and researchers about the formalin adulteration rumors.

\section{Materials and Methods}

The effect of formaldehyde on quality and post-harvest shelf life of litchi, mango and oyster mushroom were studied under laboratory condition at the Department of Food Technology and Rural Industries, Bangladesh Agricultural University (BAU), Mymensingh. The experiment was carried out during September 2014 to May 2015.

\section{Sample Selection:}

Samples of litchi, mango and mushroom were used for treatment with formaldehyde. Matured uniform samples without any bruises and deformity were selected for treatment and common maturity parameters were observed in selecting maturity. The litchis were collected from the K.R. market at BAU, fresh mangoes were collected from BAU campus, and mushrooms were collected from the Horticulture Center adjacent to BAU campus. The samples were immediately transferred to the laboratory for performing the study. Formaldehyde solutions (37\%), commonly known as formalin, and distilled water were used for the experiment.

\section{Experimental Design:}

The dipping method used for treating the samples in formaldehyde is a modified method of Brown and Dezman (1990). Four different concentrations of formaldehyde - 0\%. $1 \%, 5 \%$ and $10 \%$ were prepared. Each solution of $1 \mathrm{~L}$ was prepared in a $2 \mathrm{~L}$ plastic containers. The containers with closed lids, were placed in laboratory under room temperature. Before soaking samples into the solution, the fruits and vegetables were cleaned carefully and delicately with clean and soft tissue paper so that the skin of the fruits and vegetable remain intact. All the samples were dipped in the prepared solutions for 15 minutes to allow formaldehyde enough time to penetrate the outer layer and reach inside the fruits and vegetable. Throughout the experiment same conditions (time, temperature and atmosphere) were maintained very carefully so that for all the three sample's physical appearances can compare with each other. After 15 minutes, the samples were taken out and dried at room temperature. The dried samples were packed into a modified packaging system with $1 \%$ perforated polyethylene bags. The bags were sealed mechanically. The samples that were kept without treatment were used as the control.

\section{Evaluation of physical study}

\section{Shrinkage, freshness and change of color:}

Visual observation on shrinkage, freshness and color changes were recorded. Observation was carried at an interval of 2 days except the first observation, which was assessed just on the next day. Samples were taken out of the package and the selected physical parameters were observed carefully. The type of twisting in the surface was taken as shrinkage of skin. Color changes were recorded by taking snaps with high resolution digital camera and freshness was assessed by comparing their appearance with the fresh samples.

\section{Determination of Weight Loss:}

Weight loss was measured as a reduction in weight of the treated samples. The weights of the treated samples treated were measured on an interval of one day. The weight loss was expressed in percentage. The samples of each treatment were individually weighed by using an electric balance and kept for observation. The percent total weight loss was calculated by using the following formula:

$$
\% \text { Weight Loss }=\frac{\mathrm{IW}-\mathrm{FW}}{\mathrm{IW}} \times 100
$$

Where,

IW = initial weight of the samples, $g$

FW = final weight of samples, $g$

\section{Statistical Analysis:}

One-way analysis of variance (ANOVA), followed by ttest, was used to compare the difference between the means at 5\% significance level. Data analysis was conducted by using statistical software IBM SPSS version 23.0 for Windows (SPSS, Inc., Chicago, II., USA).

\section{Results}

\section{Effect of formaldehyde on postharvest quality of} treated samples

No significant advantages on litchi (Table 1) in terms of physical changes were observed over the control after treated with various concentrations of formaldehyde. Rather, treated litchis went for faster deterioration. The higher the concentration of formaldehyde, the faster was 
the deterioration of the color of litchis along with soft to glaireous in texture of flesh with increasing storage. Both the treated and untreated samples were found equally susceptible to microbial contamination during the last days of observation. Table 2 compares the physical changes of mango as influenced by formaldehyde treatment with different concentrations. The control samples were in acceptable condition during the entire storage time. The color of the treated samples deteriorated as the storage progressed. The color of the treated samples turned green to yellowish green with dark spots, and the texture grew soft into glaireous day by day. Microbial spoilage was observed in both the treated and untreated samples during the last days of observation. In fact, the pattern of physical changes of litichis and mangoes, due to the application of formaldehyde, was almost similar. In both the cases, the control samples remained better than the treated samples.

Table 3 presents the changes that occurred in mushroom treated with formaldehyde over the control sample. The color of the control sample became white to brown and acceptable up to two days of storage. The texture of the control sample became soft to glaireous. Significant changes in texture were observed in the treated samples over the control samples. The treated samples became elastic in texture and less brown in color with the increase in concentration of formaldehyde during the observation period. The changes in the treated samples versus control samples are clearly depicted in Plates 1-3.

\section{Effect of formaldehyde on weight of the treated samples:}

In case of litchi and mango, with varying concentration of formaldehyde, the change in mean weight loss was not significant (Table 4). But for mushroom at 5\% formaldehyde concentration, mean weight loss differed significantly from the control. At $1 \%$ and $10 \%$ concentration, the mean weight loss differed in significantly. However, at 5\% concentration, the difference in the mean weight loss of litchis, mango and mushroom was significant. But, varying results were obtained in control, $1 \%$ and $10 \%$ formaldehyde-treated samples, indicating that weight loss of fruits and vegetables is not dependent on formaldehyde application.

Table 1. Changes of physical parameters of formaldehyde treated Litchi

\begin{tabular}{|c|c|c|c|c|c|c|c|}
\hline \multirow{2}{*}{$\begin{array}{l}\text { Strength of Formal- } \\
\text { dehyde solution }\end{array}$} & \multirow[t]{2}{*}{ Observation } & \multicolumn{5}{|c|}{ Observation Period (Days) } & \multirow[b]{2}{*}{ Remarks } \\
\hline & & $\mathbf{0}$ & 1 & 3 & 5 & 7 & \\
\hline & Color & Greenish red & Greenish red & Not changed & Slight brown & Slight brown & Acceptable up \\
\hline Control & Texture & Soft & Not changed & Not changed & Dry peels & Dry peels & $\begin{array}{l}\text { to } \\
2 \text { days }\end{array}$ \\
\hline & Color & Greenish red & Dark brown & Blackish & Black & Black & Not acceptable \\
\hline $1 \%$ & Texture & Soft & Soft & Glaireous & Glaireous & Glaireous & $\begin{array}{l}\text { after } \\
\text { treatment }\end{array}$ \\
\hline $5 \%$ & Color & $\begin{array}{l}\text { Red with } \\
\text { green hue }\end{array}$ & Brown & Brown & Dark brown & Dark brown & $\begin{array}{l}\text { Not acceptable } \\
\text { after }\end{array}$ \\
\hline & Texture & Soft & Soft & Soft \& dry & Dry \& soft & Dry \& soft & treatment \\
\hline & Color & $\begin{array}{l}\text { Red with } \\
\text { green hue }\end{array}$ & Brown & Brown & Dark brown & Dark brown & $\begin{array}{r}\text { Not acceptable } \\
\text { aftertreatment }\end{array}$ \\
\hline $10 \%$ & Texture & Soft & Soft & Soft \& dry & Dry \& soft & Dry \& soft & \\
\hline
\end{tabular}

Table 2. Changes of physical parameters of formaldehyde treated Mango

\begin{tabular}{|c|c|c|c|c|c|c|c|}
\hline \multirow{2}{*}{$\begin{array}{l}\text { Strength of } \\
\text { Formaldehyde } \\
\text { solution }\end{array}$} & \multirow[b]{2}{*}{ Observation } & \multicolumn{5}{|c|}{ Observation Period (Days) } & \multirow[b]{2}{*}{ Remarks } \\
\hline & & $\mathbf{0}$ & 1 & 3 & 5 & 7 & \\
\hline \multirow[t]{2}{*}{ Control } & Color & Green & Not Changed & Not changed & Yellowish green & $\begin{array}{l}\text { Yellowish } \\
\text { Green }\end{array}$ & Acceptable \\
\hline & Texture & Characteristic. & Not Changed & Slightly ripen & Ripen & Ripen & \\
\hline \multirow[t]{2}{*}{$1 \%$} & Color & Green & $\begin{array}{l}\text { Green with } \\
\text { black spots }\end{array}$ & $\begin{array}{l}\text { Green with } \\
\text { black spots }\end{array}$ & $\begin{array}{l}\text { Yellowish green } \\
\text { with black spots }\end{array}$ & $\begin{array}{l}\text { Yellowish green } \\
\text { with black spots }\end{array}$ & \multirow{3}{*}{$\begin{array}{l}\text { Not acceptable } \\
\text { after } \\
\text { treatment } \\
\text { Not acceptable } \\
\text { after } \\
\text { treatment }\end{array}$} \\
\hline & Texture & Characteristic. & Hard & Hard & Slight soft & Soft & \\
\hline \multirow[t]{2}{*}{$5 \%$} & Color & Green & $\begin{array}{l}\text { Yellowish } \\
\text { green with } \\
\text { black spots }\end{array}$ & $\begin{array}{l}\text { Yellowish } \\
\text { green with } \\
\text { black spots }\end{array}$ & $\begin{array}{l}\text { Yellow with } \\
\text { black spots }\end{array}$ & Burnt & \\
\hline & Texture & Characteristic. & Hard & Slight soft & Soft & Glaerious & \\
\hline \multirow[t]{2}{*}{$10 \%$} & Color & Green & $\begin{array}{l}\text { Yellow with } \\
\text { black spots }\end{array}$ & $\begin{array}{l}\text { Yellow with } \\
\text { black spots }\end{array}$ & Burnt & Burnt & \multirow{2}{*}{$\begin{array}{l}\text { Not acceptable } \\
\text { after } \\
\text { treatment }\end{array}$} \\
\hline & Texture & Characteristic. & Soft & Glaerious & Glaerious & Glaerious & \\
\hline
\end{tabular}


Table 3. Changes of physical parameters of formaldehyde treated Mushroom

\begin{tabular}{|c|c|c|c|c|c|c|c|}
\hline \multirow{2}{*}{$\begin{array}{l}\text { Strength of } \\
\text { Formaldehyde } \\
\text { solution }\end{array}$} & \multirow[b]{2}{*}{ Observation } & \multicolumn{5}{|c|}{ Observation Period (Days) } & \multirow[b]{2}{*}{ Remarks } \\
\hline & & $\mathbf{0}$ & 1 & 3 & 5 & 7 & \\
\hline \multirow[b]{2}{*}{ Control } & Color & White & Not Changed & Brown Tint & Yellowish-brown & Brown & Acceptable up to \\
\hline & Texture & Soft & Not Changed & $\begin{array}{l}\text { Slightly } \\
\text { glaireous }\end{array}$ & Glaireous & $\begin{array}{l}\text { Slugde like } \\
\text { appearance }\end{array}$ & 2 days \\
\hline \multirow[t]{2}{*}{$1 \%$} & Color & White & White & White & $\begin{array}{l}\text { White with slight } \\
\text { brown color in }\end{array}$ & $\begin{array}{l}\text { White with light } \\
\text { brown hue }\end{array}$ & $\begin{array}{c}\text { Not acceptable after } \\
\text { Treatment }\end{array}$ \\
\hline & Texture & Soft & Elastic & Elastic & Elastic & Elastic & \\
\hline \multirow{3}{*}{$5 \%$} & Color & White & White & White & White & White & Not acceptable after \\
\hline & Texture & Soft & Elastic & Elastic & Elastic & Elastic & Treatment \\
\hline & Color & White & White & White & White & White & Not acceptable after \\
\hline $10 \%$ & Texture & Soft & Elastic & Elastic & Elastic & Elastic & Treatment \\
\hline
\end{tabular}

Table 4. Mean weight loss of samples at different formaldehyde concentrations with standard error mean value

\begin{tabular}{ccccc}
\hline Samples & \multicolumn{4}{c}{ Formaldehyde concentration } \\
\hline & $0 \%$ & $1 \%$ & $5 \%$ & $10 \%$ \\
\hline Litchi & $5.21 \pm 2.42(\mathrm{a})(\mathrm{A})$ & $6.90 \pm 3.32(\mathrm{a})(\mathrm{AB})$ & $5.38 \pm 2.25(\mathrm{a})(\mathrm{A})$ & $5.13 \pm 2.11(\mathrm{a})(\mathrm{A})$ \\
Mango & $2.67 \pm 0.68(\mathrm{a})(\mathrm{A})$ & $3.16 \pm 1.01(\mathrm{a})(\mathrm{A})$ & $3.02 \pm 0.76(\mathrm{a})(\mathrm{A})$ & $2.97 \pm 1.06(\mathrm{a})(\mathrm{A})$ \\
Mushroom & $24.23 \pm 5.79(\mathrm{a})(\mathrm{B})$ & $16.24 \pm 3.85(\mathrm{ab})(\mathrm{B})$ & $8.63 \pm 2.48(\mathrm{~b})(\mathrm{A})$ & $13.77 \pm 3.63(\mathrm{ab})(\mathrm{B})$ \\
\hline
\end{tabular}

${ }^{*}$ Means in a same row with same small letter are not significantly different at $0.05 \%$ significance level. Means in same with same capital letter are not significantly different at $0.05 \%$ significance level.

\section{Discussion}

Several studies found that post-harvest quality of fruits and vegetables can be influenced by a large variety of pre-harvest and genetic factors (Weston \& Barth, 1997). Generally, all phenomena (cutting, shock, loss of firmness) lead to the starting of physiological and biochemical mechanisms such as browning reactions, which induce losses or changes of flavor, odor and nutritional value (Toivonen \& Brummell, 2008). During the whole storage period in our study, no significant advantages for any of the samples treated with various concentrations of formaldehyde were observed over the control. Rather, the treated litchis and mangoes went for faster deterioration. The higher the concentration of formaldehyde in the treated samples, the faster was the deterioration of color and texture. The texture of the samples, treated with higher concentration of formaldehyde, became soft just on the second day of storage. For litchi, the texture became dry and soft on the $3^{\text {rd }}$ day for $5 \%$ and $10 \%$ formaldehyde-treated samples, while the samples treated with $1 \%$ formaldehyde became glaireous and the control sample remained unchanged up to $3^{\text {rd }}$ day of storage. Note that the observation was continued only for 7 days because of spoilage of all treated samples. On the last day, all the samples treated with formaldehyde resulted in darker color on the skin with some fungal attacks on the peel, although formaldehyde itself is a fungicide. In case of weight loss, there was no significant changes in weight in the samples treated with formalin solutions. For litchi, $5 \%$ and $10 \%$ formaldehyde-treated samples had slower weight loss than the control and 1\% formaldehydetreated samples. Some studies, however, showed the opposite result for using chemical coating or growth hormone in increasing shelf-life of litchi (Sun et al., 2010). Especially, chitosan reduced weight loss by reducing water loss and acted as a defensive barrier against bacterial contamination to ensure a prolonged shelf-life (Hernández-Muñoz et al., 2008).

All the control samples were found still fresh compared to the formaldehyde-treated samples. Corrosive properties of formaldehyde, respiration and microbial attack might be the major reasons of faster color and texture deterioration of formaldehyde treated litchis compared to the control. The fluctuation of weight loss in litchi might happen due to the restriction of respiration of the treated samples and other chemical reactions within the samples.

For mango, the situation mostly similar. No significant changes were observed in the control. One day after the treatment, the control remained unchanged, whereas $1 \%$, $5 \%$ and $10 \%$ formaldehyde-treated mangoes exhibited fresh texture, although color had changed slightly. On the $3^{\text {rd }}$ day, the control remained unchanged, but the skin of $1 \%, 5 \%$ and $10 \%$ formaldehyde-treated mango turned into burnt color, and 5\% and 10\% formaldehyde-treated mangos were fully damaged. The skin became soft and flesh started to damage. Compared to control and 1\% formaldehyde-treated mango, the condition of $5 \%$ and $10 \%$ formaldehyde-treated samples were too vulnerable, damaged and rotten. The skin became very dark, infected by microbes and the fleshes started to readily come out. At $7^{\text {th }}$ day, the color of $5 \%$ and $10 \%$ formaldehyde-treated mangoes turned into completely burnt, and the texture became very glaireous. The control was completely ripened within this time. Although 1\% formaldehyde-treated mango became soft in texture like the control, there were, however, black spots on the skin as shown in Plate 2. In mango samples, the control samples had a slightly slower rate of weight 
loss than the treated samples. But, there were no visible changes in weight loss pattern. Respiration, corrosive nature of formaldehyde and its reaction with the fruit components and microbial infection were the most possible causes of faster deterioration and stable weight loss pattern of mango.

Chitosan was proved to decrease the weight loss in mango by reducing the water loss (Chien et al., 2007). Combination of calcium chloride and gum arabic acid inhibited the decay incidence of mango. Treated fruits were delayed ripening and maintained overall quality. There were also other chemical agents, which helped to reduce the respiration rate, thus reducing the weight loss (Khaliq et al., 2016).

The case of mushroom was completely different from formaldehyde-treated litchi and mango samples. It is reported that the crude protein content of common mushroom is about 19-38 \% (Braaksma \& Schaap, 1996). On the $1^{\text {st }}$ day of storage, the color of the control turned into light yellow, whereas the color of the other samples remained as fresh and did not show any sign of deterioration of color. With progressive storage, control went on further deterioration, and on day 3, this sample was spoiled. The samples treated with $1 \%$ formaldehyde also went on to slight color change and it was a yellowish tint on the stripe. The colors of the samples, treated with 5\% and 10\% formaldehyde, were found almost unchanged. As shown in Plate 3, the control samples became brown in color, completely damaged and there was a very unpleasant smell coming out of it. Though the samples treated with formaldehyde were not damaged but their texture became elastic and the characteristic fluffiness was completely vanished. So, these samples are also unacceptable for the consumers. As mushroom contains a significant amount of protein, fixation of formaldehyde with protein might be the cause of elastic texture. Browning and some other chemical reactions were the reason of development of unexpected brown color.

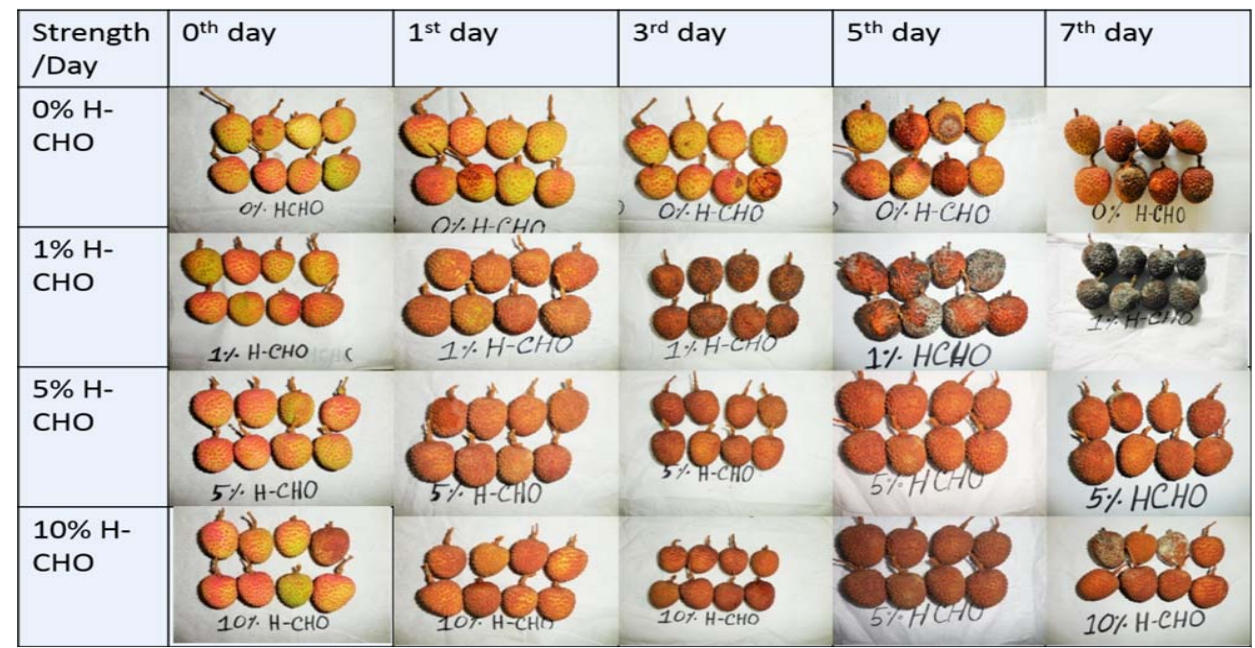

Plate 1. Effect of formaldehyde on storage quality of Litchi

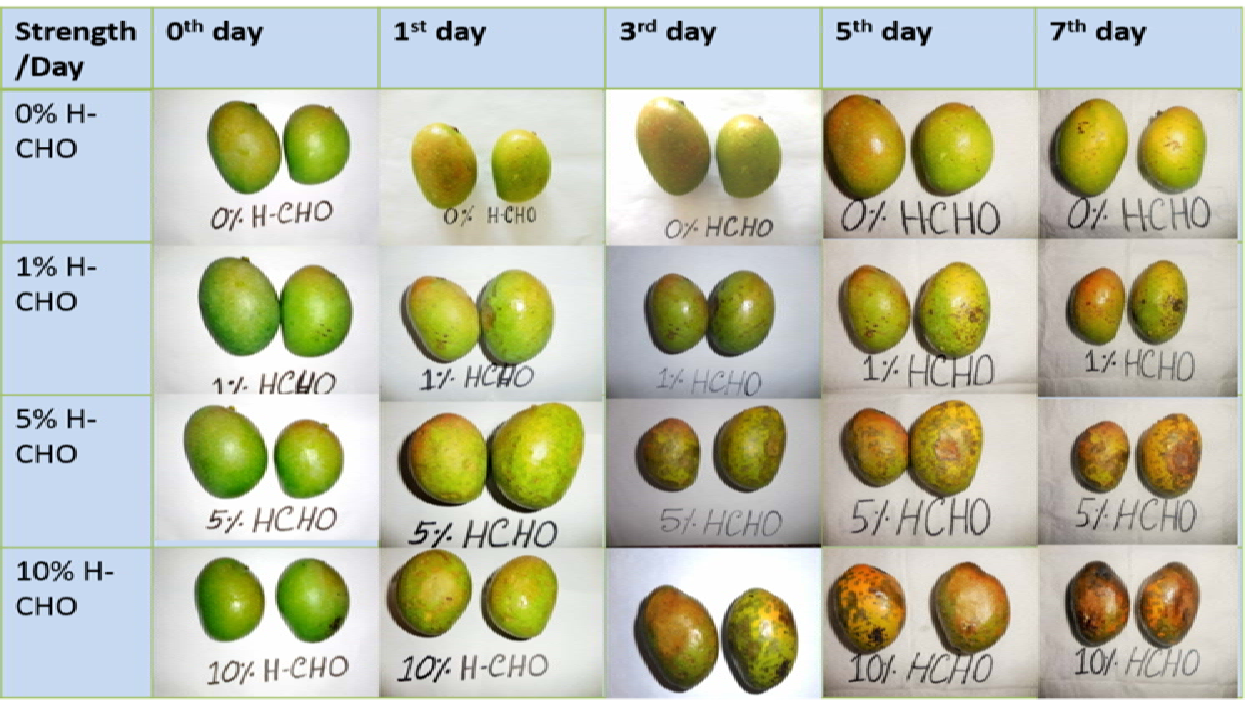

Plate 2. Effect of formaldehyde on storage quality of mango 


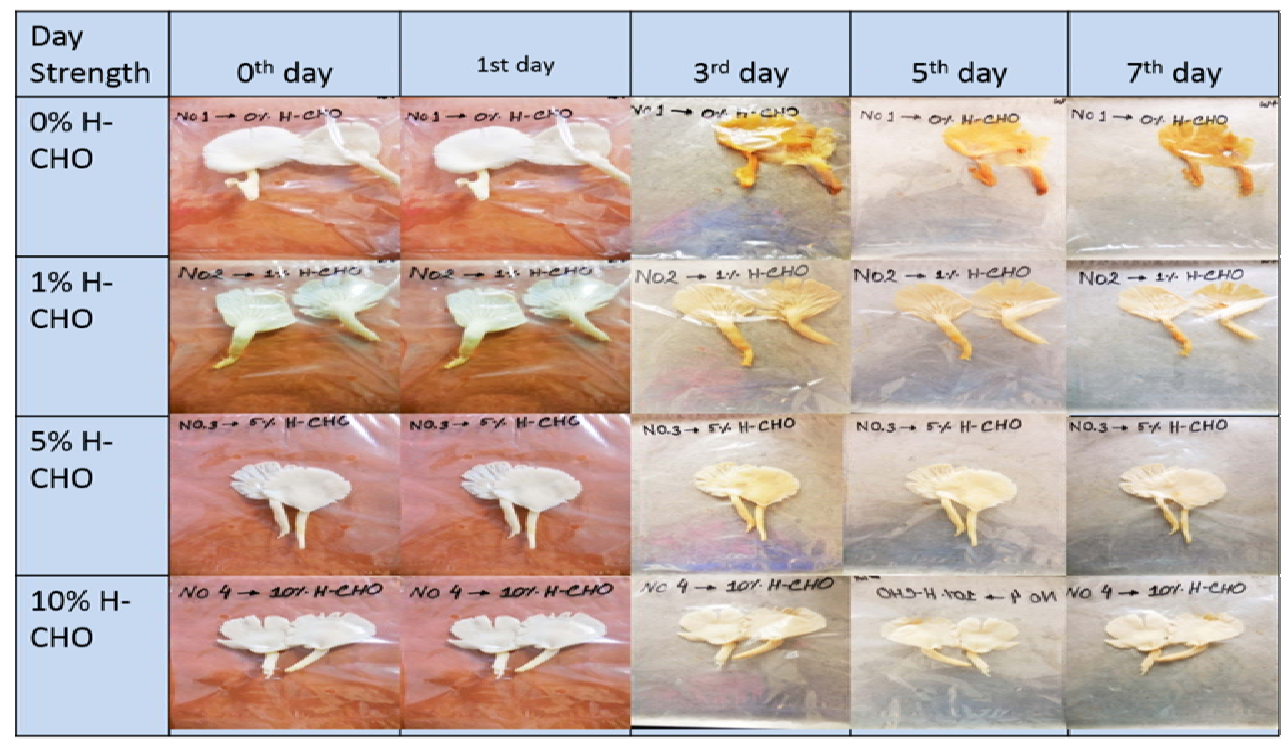

Plate 3. Effect of formaldehyde on storage quality of Mushroom

For mushroom, the result was quite different. The control sample lost weight faster than the treated samples. It is proved that formaldehyde is useful for rapid hardening of tissues as it creates fixation with protein or protenious substances (Puchtler \& Meloan, 1985).The protein in the treated mushrooms reacted with formalin and made the outer layer rigid that can be justified with the basic mechanism of formaldehyde with proteins (Kiernan, 2000).

\section{Limitations of this Study:}

This study was done primarily to observe the effect of formaldehyde on fruits and vegetables. No quantitative study was performed to determine the amount of penetration of formalin to the samples. The study was done to be sure primarily that whether formalin is used in fruits and vegetables or not. Proximate analysis of the fresh and treated samples was not done to evaluate any difference in nutritional composition. No microbial study was done to identify the microbes that grew on the surface. This study solely focused on the physiological changes in fruits and vegetables after the addition of formalin.

\section{Conclusion}

No significant advantages were observed in formaldehyde-treated samples of litchi and mango over control with respect to shelf-life and quality during storage. Rather, the treated litchis and mangoes with elevated concentration of formaldehyde went for faster deterioration. The higher the concentration of formaldehyde in solution, the faster was the deterioration of color of litchis and mangoes. In case of mushroom, shelf-life increased with increasing formaldehyde concentration. There was no significant change in weight loss of the treated and untreated litchis and mangoes. So, it is concluded that formalin does not affect the weight loss. However, opposite phenomena was observed in case of mushroom. The weight loss of mushroom was relatively slow as formaldehyde binds with the protein in mushroom. The mushrooms were the indicator that shows that formalin only works on protein to increase the shelf-life. But, on fruits and vegetables, which mostly contain carbohydrates, formalin has no influence in increasing their shelf-life; rather it has a negative impact on their shelf-life. These findings are the opposite of the general perception of people of using formaldehyde in extending shelf-life of fruits and vegetables. For further research, the amount of penetration of formalin in fruits and vegetables, and the effect of formalin on the nutritional properties needs to be done in future research.

\section{References}

Agence Francaise de Securite Sanitaire des Aliments (AFSSA). 2004. Evaluation des risquesliés à l'utilisation du formaldéhyde en alimentation animale. http://www.anses.fr/ Documents/ ALAN-Ra-formaldehyde.pdf, accessed on November, 2015.

Agency for Toxic Substances and Disease Registry (ATSDR). 1999. Toxicological Profile for Formaldehyde. US department of Health and Human Services. Atlanta, US.

Ali, A. N. M. A 2013a. Application of responsive regulation in the food safety regulations of Bangladesh. J. South Asian Stud., 1(1): 01-09.

Ali, A. N. M. A. 2013b. Food safety and public health issues in Bangladesh: a regulatory concern. Eur. Food \& Feed Law Rev., 31-40.

Badii, F. and Howell, N. K. 2003. Elucidation of the effect of formaldehyde and lipids on frozen stored cod collagen by FT-Raman spectroscopy and differential scanning calorimetry. J. Agril. Food Chem., 51(5):1440-1446.

Bhuiyan, M. N. H., Bhuiyan, H. R., Rahim, M., Ahmed, K., Haque, K. F., Hassan, M. T., and Bhuiyan, M. N. I. 2008. Screening of organochlorine insecticides (DDT and heptachlor) in dry fish available in Bangladesh. Bangladesh J. Pharmacol., 3(2):114-120.

Bianchi, F., Careri, M., Musci, M., and Mangia, A. 2007. Fish and food safety: Determination of formaldehyde in 12 fish species by SPME extraction and GC-MS analysis. Food Chem., 100(3):1049-1053.

Braaksma, A. and Schaap, D. J. 1996. Protein analysis of the common mushroom Agaricusbisporus. Posthar. Biol. Tech., 7(1): 119-127. 


\section{Antora et al.}

Brown, G.E. and Dezman, D.J. 1990. Uptake of imazalil by citrus fruit after postharvest application and the effect of residue distribution on sporulation of Penicillium digitatum. Plant disease, 74(11):927-930.

Chien, P. J., Sheu, F., and Yang, F. H. 2007. Effects of edible chitosan coating on quality and shelf life of sliced mango fruit. J. Food Engin., 78(1):225-229.

European Food Safety Authority (EFSA). 2014. Endogenous formaldehyde turnover in humans compared with exogenous contribution from food sources. EFSA J., 12(2): 3550 .

Hernández-Muñoz, P., Almenar, E., Del Valle, V., Velez, D., and Gavara, R. 2008. Effect of chitosan coating combined with postharvest calcium treatment on strawberry (Fragariax ananassa) quality during refrigerated storage. Food Chem., 110(2):428-435.

International Agency for Research on Cancer (IARC). 2004. Monographs on the evaluation of carcinogenic risks to humans, vol. 88, formaldehyde, 2-Butoxyethanol and 1tert-Butoxy-2- propanol. Lyon, France:

Kawamata, S., and Kodera, H. 2004. Reduction of formaldehyde concentrations in the air and cadaveric tissues by ammonium carbonate. Anatomic. Sci. Int., 79(3):152-157.

Khaliq, G., Mohamed, M. T. M., Ghazali, H. M., Ding, P., and Ali, A. 2016. Influence of gum arabic coating enriched with calcium chloride on physiological, biochemical and quality responses of mango (Mangifera indica L.) fruit stored under low temperature stress. Posthar. Biol. Tech., 111:362-369.

Khan, M.A. 2012a. Bitter Truth: Rampant Adulteration Plays Havoc. The Daily Star, August4, 2012. Accessed August 5, 2012.

Khan, S. M. 2012b. Toxin-Mixed Iftar Poses Serious Threat to Health. Daily Sun, July 23, 2012. Accessed November 13, 2012.

Kiernan, J. A. 2000. Formaldehyde, formalin, paraformaldehyde and glutaraldehyde: what they are and what they do. Microsc. Today, 1(5):8-12.

Mamun, M. A. A. 2014. Toxicological effect of formalin as food preservative on kidney and liver tissues in mice model. $\mathrm{J}$. Environ. Sci. Toxicol. Food Tech., 8(9):47-51.

Munim, R. 2011.Camouflaging Adulterants. The Daily Star, August 19, 2011. Accessed July 12, 2012. http://www.the dailystar.net/magazine/2011/08 /03/cover.html.

Puchtler H. and Meloan S.N. 1985. On the chemistry of formaldehyde fixation and its effects on immunohistochemical reactions. Histochemistry, 82(3):201-204.

Radomski, J. L. 1974. Toxicology of Food Colors. Ann. Rev. Pharmacol., 14:127-137.

Rahman, M. H. and Alam, M. J. B. 1997. Risk Assessment of Pesticides used in Bangladesh. J. Civil Engin., 25:97-106.
Restani, P., Restelli, A. R., and Galli, C. L. 1992. Formaldehyde and hexamethylenetetramine as food additives: chemical interactions and toxicology. Food Addi. Cont., 9(5): 597605.

Sotelo, C. G Pineiro, C., and Perez-Martin, R. I. 1995. Denaturation of fish proteins during frozen storage: role of formaldehyde. $\mathrm{Z}$ Lebensm Unters Forsch., 200:14-23.

Sun, D., Liang, G., Xie, J., Lei, X., and Mo, Y. 2010. Improved preservation effects of litchi fruit by combining chitosan coating with ascorbic acid treatment during postharvest storage. Afr. J. Biotech., 9(22):3272-3279.

Takahashi, S., Tsuji, K., Fujii, K., Okazaki, F., Takigawa, T., Ohtsuka, A., and Iwatsuki, K. 2007. Prospective study of clinical symptoms and skin test reactions in medical students exposed to formaldehyde gas. The J. dermatol., 34(5):283289.

Toivonen P.M.A. and Brummell D.A. 2008. Biochemical bases of appearance and texture changes in fresh-cut fruit and vegetables. Posthar. Biol. Technol., 48(1):1-14.

Tomkins, B. A., McMahon, J. M., Caldwell, W. M., and Wilson, D. L. 1989. Liquid chromatographic determination of total formaldehyde in drinking water. J. Asso. Offi. Analytic. Chemis., 72(5):835-839.

Uddin, R., Wahid, M. I., Jasmeen, T., Huda, N. H., and Sutradhar, K. B. 2011. Detection of formalin in fish samples collected from Dhaka City, Bangladesh. Stamf. J. Pharmaceu. Sci., 4(1): 49-52.

United Nations (UN). 2012. The state of the world's children 2008: Child survival. In United Nations International Children's Emergency Fund, December 2007: 1, http://www.unicef. org/sowc08/docs/sowc08.pdf, Accessed November 15

Wahed, P., Razzaq, M. A., Dharmapuri, S., and Corrales, M. 2016. Determination of formaldehyde in food and feed by an inhouse validated HPLC method. Food chem., 202:476-483.

Weston, L.A. and Barth, M.M. 1997. Preharvest factors affecting postharvest quality of vegetables. Hort. Sci., 32(5): 812816.

World Health Organization (WHO). 2006. IARC Monographs on the Evaluation of Carcinogenic Risks to Humans. Formaldehyde, 2-Butoxyethanol and 1-tert-Butoxy-2propanol, 88.

World Health Organization (WHO). 2000. Air quality guidelines for Europe.

http://www.euro.who.int/__data/assets/pdf_file/0005/74732 /E71922.pdf , last accessed November , 2015. 